Artykuły

Studia Iuridica Lublinensia vol. XXVI, 1, 2017

DOI: 10.17951/sil.2017.26.1.13

\title{
Paweł Czechowski
}

Uniwersytet Warszawski

p.czechowski@wpia.uw.edu.pl

\section{Skutek intertemporalny nowelizacji ustawy z dnia 26 czerwca 2009 r. o zmianie ustawy o księgach wieczystych i hipotece oraz niektórych innych ustaw}

\author{
Intertemporal Effect of the Amendment of the Act of 26 June 2009 \\ on the Amendment of the Law on Land Registers and Mortgage \\ and Certain Other Acts
}

\section{STRESZCZENIE}

W artykule wskazano problematykę skutku intertemporalnego (międzyczasowego) nowelizacji ustawy z dnia 26 czerwca 2009 r. o zmianie ustawy o księgach wieczystych i hipotece oraz niektórych innych ustaw. Wprowadzone przez powyższą nowelizację zasady intertemporalne jednoznacznie wskazują, że od 20 lutego 2011 r., tj. od daty wejścia w życie ustawy (art. 14), W obrocie prawnym funkcjonują trzy zróżnicowane systemy prawne dotyczące hipotek. Wejście w życie powyższej nowelizacji, tj. ustawy z dnia 26 czerwca 2009 r., ma istotne znaczenie z punktu widzenia stosowania przepisów dotychczasowych lub nowych po nowelizacji, w szczególności do hipoteki umownej - zwykłej i kaucyjnej. Istotną cezurą czasową dla określenia, czy stosuje się przepisy dotychczasowe czy też nowe, jest data 20 lutego $2011 \mathrm{r}$.

Słowa kluczowe: hipoteka; hipoteka kaucyjna; zasady intertemporalne; zamiana nieruchomości; hipoteka zwykła

Nowelizacja ustawy z dnia 26 czerwca 2009 r. o zmianie ustawy o księgach wieczystych i hipotece oraz niektórych innych ustaw ${ }^{1}$ w drodze art. 10 normuje podstawowe zasady intertemporalne (międzyczasowe) związane ze stosowa-

${ }^{1}$ Dz.U., nr 131, poz. 1075, dalej jako: u.k.w.h. 
niem do zabezpieczeń hipotecznych przepisów dotychczasowych oraz przepisów wprowadzonych $\mathrm{w}$ drodze przedmiotowej nowelizacji. Wprowadzone przez powyższą nowelizację zasady intertemporalne jednoznacznie wskazują, że od 20 lutego 2011 r., tj. od daty wejścia w życie ustawy (art. 14), w obrocie prawnym funkcjonują trzy zróżnicowane systemy prawne dotyczące hipotek.

Jak trafnie wskazano w literaturze²:

Hipoteki podlegają zróżnicowanym reżimom prawnym:

- hipoteki zwykłe i związane z nimi hipoteki kaucyjne zabezpieczające roszczenia uboczne, do których stosuje się dotychczasowe przepisy ustawy o księgach wieczystych i hipotece, z wyjątkiem art. 76 ust. 1 i 4 mających zastosowanie w zmiennym brzmieniu,

- hipoteki kaucyjne, które podlegają znowelizowanym przepisom ustawy o księgach wieczystych i hipotece, z wyjątkiem przepisów o rozporządzeniu opróżnionym miejscem hipotecznym (art. $101^{1} \mathrm{i} \mathrm{n}$.),

- hipoteki o znowelizowanej konstrukcji, do których w pełni mają zastosowanie zmienione przepisy ustawy o księgach wieczystych i hipotece.

Nadmienić należy, że powyższa nowelizacja ustawy z dnia 20 czerwca 2009 r. stworzyła określone stany prawne, powiązane ściśle ze zróżnicowaną terminologią prawną, które wyraźnie rozgraniczają stosowanie przepisów dotychczasowych do hipoteki (hipotek) ustanowionej przed dniem wejścia w życie nowelizacji ustawy, tj. przed 20 lutego $2011 \mathrm{r}$.

Dotyczy to przypadków powstania hipoteki na podstawie znowelizowanej ustawy po 20 lutego 2011 r. Nie ulega wątpliwości, że instytucja hipoteki w polskim systemie prawnym stanowi najbardziej stabilne zabezpieczenie rzeczowe na nieruchomości oraz niektórych prawach dotyczących nieruchomości. Hipoteka zabezpiecza wierzytelności związane $\mathrm{z}$ finansowaniem długoterminowym i odgrywa ważną rolę $\mathrm{w}$ ochronie wierzycieli przed nierzetelnymi dłużnikami poprzez uniemożliwienie im wyzbywania się w sposób niekontrolowany przez wierzycieli majątku stanowiącego ich zabezpieczenie. Nowelizacja ustawy z dnia 26 czerwca 2009 r., o której wspomniano powyżej, ujednoliciła obowiązujący przed nowelizacją system hipoteki, znosząc jej dotychczasowy podział na hipotekę zwykłą i kaucyjną.

Nowelizacja ustawy wdraża również nowe konstrukcje prawne. Wejście w życie powyższej nowelizacji, tj. ustawy z dnia 26 czerwca 2009 r., ma istotne znaczenie z punktu widzenia stosowania przepisów dotychczasowych lub nowych po nowelizacji, w szczególności do hipoteki umownej - zwykłej i kaucyjnej. Istotną cezurą czasową dla określenia, czy stosuje się przepisy dotychczasowe czy też nowe, jest data 20 lutego $2011 \mathrm{r}$.

Otóż do stanów prawnych powstałych przed 20 lutego 2011 r. stosuje się przepisy dotychczasowe. Natomiast po 20 lutego 2011 r. stosuje się przepisy znowelizowane w u.k.w.h. Wyjątek stanowi powoływany przez art. 10 ust. 2 zd. 1 ustawy

\footnotetext{
${ }^{2}$ Por. T. Czech, Hipoteka. Komentarz, Warszawa 2011, s. 666.
} 
nowelizującej art. 76 ust. 1 i 4, który stosuje się w brzmieniu nadanym przez nowelizację. W literaturze prawniczej podkreślono, że powyższy przepis został zredagowany nieprecyzyjnie ${ }^{3}$. Przychylając się do tego poglądu, w przypadku braku precyzji przepisu prawnego należy zastosować logikę prawniczego wnioskowania.

Analizowana problematyka dotyczy w szczególności możliwości powstania hipotek zwykłych po dniu 20 lutego 2011 r. T. Czech, autor jednego z wiodących komentarzy do instytucji hipoteki, opowiada się za odejściem od wykładni językowej art. 10 ust. 2 zd. 1 ustawy nowelizacyjnej, jak następuje:

Hipoteki zwykłe mogą powstawać także po wejściu w życie nowelizacji z 26 czerwca 2009 r. Komentowany przepis nie może dotyczyć tylko hipotek zwykłych „powstałych” przed wejściem w życie nowelizacji, ponieważ poza polem unormowania pozostałyby hipoteki zwykłe, które powstały (zostały wpisane) po 20 lutego $2011 \mathrm{r}$.

Artykuł 10 ust. 2 zd. 1 nowelizacji z 26 czerwca 2009 r. przewiduje wyjątek od dalszego działania ustawy dawnej. Wyjątek ten dotyczy dwóch przepisów - art. 76 ust. 1 i 4, które od 20 lutego 2011 r. stosuje się do hipotek zwykłych w brzmieniu nadanym nowelizacją. Przepisy te regulują skutki podziału nieruchomości.

Po 20 lutego 2011 r. wierzyciel hipoteczny oraz właściciel nieruchomości mogą zmienić zawartą uprzednio - umowę o ustanowienie hipoteki zwykłej, określić sposób podziału hipoteki oraz złożyć wniosek o ujawnienie tego sposobu w księdze wieczystej. Postanowienie umowne dotyczące uzgodnionego sposobu podziału hipoteki zwykłej będzie wtedy skuteczne w odniesieniu do podziałów obciążonej nieruchomości, których dokonano po chwili złożenia tego wniosku, jeżeli - oczywiście - wniosek rozpatrzono pozytywnie (art. 76 ust. 4 zd. 2 w zw. z art. 29 u.k.w.h. W zw. z art. 10 ust. 2 zd. 1 nowelizacji z 26 czerwca 2009 r.).

Odnotować należy również, że w literaturze przedmiotu istnieje stanowisko odmienne od prezentowanego powyżej stanowiska T. Czecha, które przedstawił J. Pisuliński w komentarzu Hipoteka po nowelizacji ${ }^{4}$.

Powyższe regulacje dotyczące hipoteki odnoszą się także do hipoteki łącznej. Hipotekę łączną stanowi zbiór powiązanych ze sobą hipotek. Hipoteka łączna to jedna hipoteka, która jednocześnie obejmuje wiele przedmiotów głównych zabezpieczenia. Wobec braku ograniczeń co do przedmiotu hipoteki łącznej, mogą nią być obciążone nieruchomości budynkowe, gruntowe, lokalowe czy będące w użytkowaniu wieczystym itp. W hipotece łącznej celem jest zabezpieczenie tych samych wierzytelności, a wierzyciel ma swobodę wyboru nieruchomości, z których będzie dochodził zaspokojenia. Konstrukcja normatywna hipoteki łącznej nie odbiega od ogólnej konstrukcji hipoteki

Hipoteka łączna może powstać z mocy ustawy (art. 76 ust. 3), w drodze czynności prawnej umownej oraz w sposób przymusowy (art. 111') i wpisu do księgi wieczystej.

${ }^{3}$ Por. ibidem, s. 674 i n.

${ }^{4}$ J. Pisuliński, Hipoteka po nowelizacji. Komentarz, Warszawa 2011, s. 36-37.

${ }^{5}$ Por. H. Ciepła, E. Bałan-Gonciarz, Ustawa o ksieggach wieczystych i hipotece. Komentarz po nowelizacji prawa hipotecznego, Warszawa 2011, s. 117-119. 
Zakazane jest łączenie różnych trybów powstania hipoteki łącznej w odniesieniu do nieruchomości objętych powyższą hipoteką:

- w przypadku hipoteki ustawowej, gdy w wyniku sprzedaży części nieruchomości obciążonej hipoteką sprzedający lub kupujący mogą żądać, by wierzyciel hipoteczny zwolnił powyższą część nieruchomości od obciążenia, jeżeli jest ona stosunkowo nieznaczna, a wartość pozostałej części nieruchomości zapewnia wierzycielowi dostateczne zabezpieczenie (art. 90),

- w przypadku hipoteki łącznej umownej, gdy strony zgodnie z art. 76 ust. 3 mają kompetencje, w drodze czynności prawnej, do obciążania jedną hipoteką dwóch lub więcej nieruchomości.

Nadmienić należy, że wyznaczona suma hipoteczna obciążenia nie posiada normatywnego związku z wysokością zaspokojenia i liczbą zabezpieczonych wierzytelności (art. 68 ust. 2 zd. 1). Wykonywanie przez wierzycieli uprawnień z hipoteki łącznej (z uwzględnieniem klauzuli generalnej art. 5 k.c.) zgodnie z art. 76 ust. 2 zd. 1 charakteryzuje się swobodą decyzji. Oznacza to, że mogą oni dochodzić od dłużników hipotecznych zaspokojenia w całości lub części zabezpieczonych wierzytelności.

Jak wspomniano powyżej, wierzyciel posiada prawo dokonania wyboru nieruchomości objętej hipoteką łączną, z której zamierza dochodzić zaspokojenia wierzytelności z uwzględnieniem art. 1039 k.p.c., tj. złożenia oświadczenia określającego wysokość zaspokojenia z każdej z nieruchomości. Zgodnie z art. 76 ust. 2 wierzyciel może dokonać podziału hipotek pomiędzy poszczególne nieruchomości.

Jak wskazano w literaturze przedmiotu, wierzyciel może zwolnić niektóre nieruchomości z obciążenia hipotecznego. Wygaśnięcie hipotek na niektórych nieruchomościach nie skutkuje wygaśnięciem pozostałych, co stwarza możliwość dopuszczalności wystąpienia zróżnicowania sytuacji prawnej właścicieli tych nieruchomoścí.

O ocenie czynności prawnej w płaszczyźnie intertemporalnej, w związku z wejściem w życie nowelizacji z dnia 26 czerwca 2009 r., decyduje reguła obowiązywania przepisów, jakie obowiązywały w momencie, w którym dokonano czynności.

Powyższe stanowisko akceptuje SN w postanowieniu z dnia 2 lipca 2004 r. ${ }^{7}$, w którym stanowi, że „o tym, jakie normy mają zastosowanie do rozstrzygania stanu faktycznego, decydują przepisy prawa materialnego regulujące dany stosunek prawny. One także decydują, czy w sytuacji zmiany stanu prawnego sąd do rozstrzyganego stosunku prawnego powinien zastosować przepisy nowe czy dawne".

Nowelizacja ustawy unormowała również reżim prawny hipoteki kaucyjnej. Hipoteka kaucyjna zabezpiecza samodzielnie wierzytelności wraz z roszczeniami ubocznymi.

${ }^{6}$ Por. ibidem, s. 119. Zob. także: postanowienie SN z dnia 4 grudnia 2009 r., VII CZP 101/09, LEX nr 565646.

7 II CK 421/63, LEX nr 174137. 
Jak wspomniano powyżej, podobnie jak w odniesieniu do hipoteki zwykłej, w tym hipoteki łącznej, powstaje pytanie o zastosowanie art. 10 ust. 1 nowelizacji z dnia 26 czerwca 2009 r. do hipotek kaucyjnych, tj. czy hipoteki kaucyjne, zgodnie z językową zasadą interpretacji tekstu nowelizowanej ustawy, podlegają normom przepisów ustawy o księgach wieczystych i hipotece czy tylko przepisom o opróżnionym miejscu hipotecznym.

Podzielając interpretacje przedstawione przez T. $\mathrm{Czecha}^{8}$, należy przyjąć pogląd, że status hipoteki kaucyjnej powstałej po 20 lutego 2011 r. według wykładni systemowej i funkcjonalnej był zgodny z wolą ustawodawcy, którego celem było jednolite unormowanie wszystkich rodzajów hipotek (hipoteki zwykłej, hipoteki kaucyjnej samodzielnej i zabezpieczającej roszczenia uboczne).

Zgodnie z powoływanym powyższym poglądem ustawodawca, na co wskazuje także uzasadnienie projektu ustawy nowelizacyjnej, nie zamierzał różnicować reguły intertemporalnej w zależności od tego, czy hipoteka danego rodzaju uzyskuje skuteczność przed dniem 20 lutego 2011 r. czy też począwszy od tego terminu.

Rekapitulując powyższe wywody, stwierdzić należy, że nowelizacja z dnia 26 czerwca 2009 r. odnosząca się do hipoteki kaucyjnej wywołuje skutki retrospektywne. Hipoteka kaucyjna ustanowiona przed dniem wejścia w życie nowelizacji podlega dotychczasowym przepisom ustawy, a w okresie od 20 lutego $2011 \mathrm{r}$. do hipoteki kaucyjnej stosuje się przepisy działania nowej ustawy.

Wskazać należy także na pogląd zaprezentowany w literaturze przedmiotu ${ }^{9}$ mówiący o tym, że do hipotek kaucyjnych nie stosuje się znowelizowanych przepisów ustawy o księgach wieczystych i hipotece, lecz przepisy dotychczasowe z uwzględnieniem brzmienia art. 16 ust. 2 zd. 2 ustawy nowelizacyjnej, z zastosowaniem art. 76 ust. 4 u.k.w.h. ${ }^{10}$

Zastosowanie przepisów znowelizowanej ustawy po 20 lutego 2011 r. do hipoteki kaucyjnej zachodzi m.in. w przypadku występowania tzw. nadmierności zabezpieczenia. Właściciel nieruchomości może żądać zmniejszenia sumy hipoteki kaucyjnej (art. 68 ust. 2 znowelizowanej u.k.w.h.). Dotyczy to sytuacji, gdy nadmierność zabezpieczenia powstała przed datą wejścia w życie nowelizacji z dnia 26 czerwca 2009 r., tj. 20 lutego 2011 r., jak również po tej dacie ${ }^{11}$.

Powyższe rozwiązanie ma na celu zmniejszenie zależności między zabezpieczoną wierzytelnością a sumą hipoteczną i służy dostosowaniu sumy hipotecznej do rzeczywistego zabezpieczenia interesu wierzyciela hipotecznego.

Uprawnienie właściciela do zmniejszenia sumy hipotecznej realizowane jest w drodze sądowej w powództwie o ukształtowanie prawa (art. 13 ust. 2 zd. 1 k.p.c.). Zgodnie z art. 68 ust. 2 zd. 2 nadmierność oznacza, że suma hipoteczna, wyrażona

\footnotetext{
${ }^{8}$ T. Czech, Księgi wieczyste i hipoteka. Komentarz, Warszawa 2014, s. 1535 i n.

9 J. Pisuliński, op. cit., s. 37.

${ }^{10}$ Por. także: uchwała 7 sędziów SN z dnia 16 października 2008 r., III CZP 71/08, OSN 2009.

${ }^{11}$ Por. T. Czech, Hipoteka ..., s. 681.
} 
w wartościach pieniężnych określających wysokość odpowiedzialności hipotecznej, jest wyższa od sumy wszystkich roszczeń, w tym roszczeń o świadczenia uboczne i wierzytelności przyszłe. Powoływany przepis ma na celu dostosowanie zabezpieczenia do rzeczywistych potrzeb wierzyciela ${ }^{12}$. Odnotować należy również pogląd, że powyższe uprawnienia właściciela nieruchomości odnoszą się do każdego rodzaju hipoteki, niezależnie od sposobu jej powstania. Powszechne jest przyjęcie reguły interpretacyjnej, że suma hipoteczna nieprzekraczająca $150 \%$ łącznych kwot wierzytelności i roszczeń o świadczenia uboczne objętych hipoteką nie powoduje nadmierności zabezpieczenia. A contrario suma hipoteczna przekraczająca powyższy poziom łącznych kwot wierzytelności uznawana jest za nadmierność zabezpieczenia ${ }^{13}$.

Przykładem stosowania regulacji dawnej, która nie była przedmiotem nowelizacji z dnia 26 czerwca 2009 r., jest art. 90 u.k.w.h. Dotyczy on podziału fizycznego nieruchomości w razie sprzedaży części nieruchomości obciążonej hipoteką. Sprzedawca lub kupujący może żądać, by wierzyciel zwolnił tę część od obciążenia, jeżeli jest ona stosunkowo nieznaczna, a wartość pozostałej części nieruchomości zapewnia wierzycielowi dostateczne zabezpieczenie (art. 90 zd. 1). Nie budzi również zastrzeżeń, że art. 90 stosuje się na zasadach analogii do umowy zamiany części nieruchomości.

Zwolnienie hipoteki oznacza czynność prawną polegającą na zrzeczeniu się przez wierzyciela prawa hipotecznego (art. 246 k.c.). Wykładnia językowa powyższego przepisu wskazuje, że roszczenie powstaje z chwilą zawarcia umowy sprzedaży nawet $\mathrm{w}$ przypadku, gdyby nie wywarła skutku rozporządzającego. Negocjacje dotyczące zwolnienia hipoteki odbywają się z reguły jeszcze przed zawarciem umowy sprzedaży.

Podzielić należy trafny pogląd sformułowany w literaturze przedmiotu, że art. 90 na zasadach analogii należy stosować także w przypadku, w którym hipoteka łączna obciąża dwie lub więcej nieruchomości, a właściciel w całości sprzedaje jedną $\mathrm{z}$ tych nieruchomości ${ }^{14}$.

Jak wskazano powyżej, w przypadku hipoteki łącznej stosowanie art. 90 na zasadach analogii znajduje odniesienie do zamiany jednej z nieruchomości. Każdej ze stron umowy przysługuje roszczenie o zwolnienie spod obciążenia zbytej nieruchomości.

Zastosowanie analogii odnośnie do dopuszczenia zamiany nieruchomości uwzględniać powinno fakt, że w przypadku zamiany nieruchomości o zbliżonej wartości, gdy nabyta, zamieniona nieruchomość zostaje przyłączona do istniejących obciążanych nieruchomości, staje się przez to przedmiotem hipoteki. W po-

12 Por. Ł. Przyborowski, Hipoteka po nowelizacji z dnia 29 czerwca 2009 r., „Rejent” 2011, nr 1, s. 189-193.

${ }^{13}$ Por. T. Czech, Hipoteka..., s. 130-133.

${ }^{14}$ Por. idem, Księgi wieczyste..., s. 1190. 
wyższym stanie faktycznym odłączona nieruchomość powinna zostać zwolniona spod obciążenia wobec braku wystąpienia zagrożenia interesu wierzyciela hipotecznego. Zapewnienie wierzycielowi zabezpieczenia jego interesów powinno znajdować odzwierciedlenie w wartości pozostałych nieruchomości stanowiących zabezpieczenie, które jednocześnie nie może być niższe niż suma hipoteki.

Zastosowanie przepisu art. 90 u.k.w.h. uwarunkowane jest występowaniem obciążenia, które określone jest jako nieznaczne. Wartość pozostałej części nieruchomości lub nieruchomości w przypadku hipoteki łącznej zapewnia wierzycielowi dostateczne zabezpieczenie.

Wskazać należy, że w przypadku występowania nadmierności zabezpieczenia zastosowanie art. 90 u.k.w.h. jest w pełni uzasadnione nawet w przypadku, gdy właściciel nieruchomości nie żąda zmniejszenia hipoteki.

Zwolnienie od obciążenia hipoteką sprzedanej części nieruchomości lub zamiany nieruchomości, w przypadku wystąpienia nadmierności zabezpieczenia, nie narusza bezpieczeństwa hipoteki przysługującej wierzycielowi. Dotyczy to również zamiany nieruchomości o zbliżonej wartości ekwiwalentności zabezpieczenia hipotecznego, w tym zamiany nieruchomości obciążonych hipoteką łączną zwykłą i kaucyjną, ustanowioną przed dniem 20 lutego $2011 \mathrm{r}$.

Zgodnie z tradycyjnym poglądem doktryny prawa, akceptowanym przez judykaturę, istotą hipoteki łącznej jest wielość praw obciążających poszczególne nieruchomości, co oznacza, że hipotek jest tyle, ile jest obciążonych nieruchomości, przy czym hipoteki te cechuje wzajemny związek wynikający z zabezpieczenia tej samej wierzytelności ${ }^{15}$. W związku z powyższym zamiana nieruchomości dotychczas współobciążonej hipoteką łączną zwykłą i kaucyjną na nieruchomość wolną od obciążeń, której wartość jest ekwiwalentna, mająca zabezpieczać ten sam stosunek zobowiązaniowy, nie doprowadzi do zmiany zajmowanego miejsca hipotecznego przez pozostałe ze współobciążonych nieruchomości.

Wyrażam pogląd, który znajduje odniesienie w postanowieniu Sądu Najwyższego z dnia 16 stycznia 2014 r. (IV CSK 207/2013), że zamiana taka jest możliwa, o ile po wykreśleniu jednej z nieruchomości obciążonych hipoteką łączną, hipoteka ta nie straci cech hipoteki łącznej, co oznacza, iż nadal będzie obciążać co najmniej dwie nieruchomości, a wierzyciel będzie nadal należycie zabezpieczony przez uprzednie objęcie hipoteką łączną zwykłą lub kaucyjną nowej nieruchomości, której wartość będzie ekwiwalentna do nieruchomości, którą dłużnik chce zwolnić z obciążenia hipotecznego.

Jak stwierdził Sąd Najwyższy w powołanym postanowieniu, z regulacji zawartej w art. 10 ust. 1 u.k.w.h., po wejściu w życie tej ustawy, nie wynika zakaz objęcia hipoteką umowną łączną hipoteki kaucyjnej wpisanej przed dniem 20 lutego 2011 r.

${ }^{15}$ Por. idem, Hipoteka..., s. 287. 
Przedstawiona powyżej argumentacja jednoznacznie wskazuje, że analizowane czynności prawne, tj. zwolnienie od obciążenia części nieruchomości, całości nieruchomości lub zamienionej nieruchomości, są zgodne z przepisami u.k.w.h. Problematyka działania u.k.w.h. po nowelizacji odnośnie do brzmienia art. 10 ust. 1, dotycząca przepisów o rozporządzanym opróżnionym miejscu hipotecznym, stanowi pewną rozbieżność interpretacyjną w literaturze przedmiotu.

Zgodnie z art. 10 ust. 1 ustawy nowelizującej z dnia 26 czerwca 2009 r.: „Do hipotek kaucyjnych powstałych przed dniem wejścia w życie niniejszej ustawy, z zastrzeżeniem ust. 2, stosuje się przepisy ustawy, o której mowa w art. 1, w brzmieniu nadanym niniejszą ustawą, z wyjątkiem przepisów o rozporządzaniu opróżnionym miejscem hipotecznym". W celu wyjaśnienia przepisu wskazać należy, że powoływany powyżej art. 1 ustawy określa zakres stosowania ksiąg wieczystych uregulowanych $w$ u.k.w.h. Istota problemu dotyczy odpowiedzi na pytanie, czy wyjątek od zasady bezpośredniego działania ustawy nowelizującej dotyczy jedynie przepisów o rozporządzanym opróżnionym miejscu hipotecznym czy też ma szerszy zakres przedmiotowy.

Autorzy dwóch wiodących komentarzy prawnych do hipoteki prezentują zróżnicowane stanowiska. T. Czech twierdzi, że:

[...] należy przyjąć rozszerzającą wykładnię art. 10 ust. 1 in fine nowelizacji z 26 czerwca 2009 r. i uznać, że do hipoteki kaucyjnej stosuje się - oprócz reguły „posuwania się hipotek naprzód" - także niektóre inne z dotychczasowych przepisów ustawy o księgach wieczystych i hipotece. [...] Listę wyjątków należy poszerzyć o dotychczasowy art. 70, zgodnie z którym zmiany dotyczące wierzytelności hipotecznej, naruszające prawa obciążające nieruchomość z pierwszeństwem równym lub niższym, wymagają zgody osób, którym prawa te przysługują (przy czym nie dotyczy to zmiany terminów płatności). Powołany przepis jest ściśle sprzężony z zasadą „posuwania się hipotek naprzód". Osoby, którym przysługują prawa z pierwszeństwem równym lub niższym, mogą zasadnie oczekiwać, że po wygaśnięciu hipoteki kaucyjnej ich prawa odpowiednio „awansują" w hierarchii wykonywania i zaspokojenia. [...]

Mechanizm ten pozostaje aktualny także po wejściu w życie nowelizacji z 26 czerwca 2009 r. Nie można dopuścić wykładni, która - w odniesieniu do hipoteki kaucyjnej - utrzymywałaby zasadę „posuwania się hipotek naprzód”, a jednocześnie podważałaby tę zasadę, wyłączając stosowanie art. 70. Wykładnia taka, przynajmniej w niektórych przypadkach, naruszałaby chronione konstytucyjnie uprawnienia osób trzecich. [...]

Powyższe argumenty przemawiają za wnioskiem, że - wbrew wykładni językowej art. 10 ust. 1 in fine nowelizacji z 26 czerwca 2009 r. - po 20 lutego 2011 r. do hipoteki kaucyjnej nadal stosuje się dotychczasowy art. $70^{16}$.

Oznacza to, że zgodnie z art. 70 (uchylonym przez ustawę nowelizacyjną z dnia 26 czerwca 2009 r.) ,zmiany dotyczące wierzytelności hipotecznej, naruszające prawa obciążające nieruchomości z pierwszeństwem równym lub niższym, wymagają zgody osób, którym prawa te przysługują. Nie dotyczy to zmiany terminów płatności".

${ }^{16}$ Ibidem, s. 682. 
Natomiast zgodnie ze stanowiskiem prezentowanym przez J. Pisulińskiego ${ }^{17}$ :

[...] w drodze wyjątku od hipotek kaucyjnych powstałych przed dniem 20 lutego $2011 \mathrm{r}$. jednak nie będą miały zastosowania przepisy o rozporządzaniu opróżnionym miejscem hipotecznym, co było uzasadnione tym, że wierzyciele hipoteczni mogli liczyć przed wprowadzeniem instytucji rozporządzania opróżnionym miejscem hipotecznym, że ich hipoteki posuną się naprzód, jeśli wygaśnie hipoteka poprzedzająca ich prawa. Należy to rozumieć w ten sposób, że w razie wygaśnięcia hipoteki kaucyjnej po dniu 19 lutego 2011 r. właściciel nieruchomości nie będzie mógł na opróżnionym miejscu ustanowić nowej hipoteki ani przenieść na to miejsce innej hipoteki; dojdzie natomiast do przesunięcia innych hipotek obciążających tę nieruchomość z pierwszeństwem niższym od wygasłej hipoteki kaucyjnej. Natomiast dopuszczalne będzie przesunięcie powstałej przed dniem 20 lutego 2011 r. hipoteki kaucyjnej na opróżnione miejsce hipoteczne po wygasłej hipotece, jeżeli wygasła hipoteka została ustanowiona po dniu 19 lutego $2011 \mathrm{r}$.

Poszukując optymalnego rozwiązania, należy opowiedzieć się za interpretacją prezentowaną przez T. Czecha odnośnie do wykładni rozszerzającej art. 10 ust. 1, która stanowi pełniejszą ochronę interesów wierzycieli, na rzecz których ustanowiono hipotekę kaucyjną. Wobec braku precyzyjnej redakcji powyższego przepisu uwzględniającego stan intertemporalny trudno określić, jaką linię orzecznictwa przyjmą sądy prowadzące księgi wieczyste.

\section{BIBLIOGRAFIA}

Ciepła H., Bałan-Gonciarz E., Ustawa o księgach wieczystych i hipotece. Komentarz po nowelizacji prawa hipotecznego, Warszawa 2011.

Czech T., Hipoteka. Komentarz, Warszawa 2011.

Czech T., Księgi wieczyste i hipoteka. Komentarz, Warszawa 2014.

Pisuliński J., Hipoteka po nowelizacji. Komentarz, Warszawa 2011.

Postanowienie SN z dnia 2 lipca 2004 r., II CK 421/63, LEX nr 174137.

Postanowienie SN z dnia 4 grudnia 2009 r., VII CZP 101/09, LEX nr 565646.

Postanowienie SN z dnia 16 stycznia 2014 r., IV CSK 207/2013.

Przyborowski Ł., Hipoteka po nowelizacji z dnia 29 czerwca 2009 r., „Rejent” 2011, nr 1.

Uchwała 7 sędziów SN z dnia 16 października 2008 r., III CZP 71/08, OSN 2009.

Ustawa z dnia 26 czerwca 2009 r. o zmianie ustawy o księgach wieczystych i hipotece oraz niektórych ustaw (Dz.U., nr 131, poz. 1075).

\section{SUMMARY}

The article presents the problem of the intertemporal effect of the amendment of the Act of 26 June 2009 on the amendment of the law on land registers and mortgage and certain other acts. The introduced intertemporal regulations directly indicate that since the date of entry into force of the Act (Art. 14), i.e. 20 February 2011, there exist three varying legal systems concerning land registers. Entering into force of the above-mentioned amendment, i.e. the Act of 26 June 2009, is fundamental from the point of view of the application of both existing regulations and new ones,

${ }^{17}$ J. Pisuliński, op. cit., s. 38. 
Pobrane z czasopisma Studia Iuridica Lublinensia http://studiaiuridica.umes.pl Data: 26/04/2023 03:04:11

especially those concerning the contractual mortgage - both ordinary and capped. The date of 20 February 2011 constitutes a significant caesura which is used for determining whether the existing regulations or the new ones are applied.

Keywords: mortgage; capped mortgage; the principle of intertemporal; exchange of real estate; mortgage 